\title{
Books Available for Review
}

The following books are available for review. A book that you review is yours to keep. If you request a book and then decide not to review the book, return it within six months. Requests should be addressed to:

\section{Book Review Editor, Auslegung \\ Department of Philosophy \\ University of Kansas \\ 1445 Jayhawk Blvd, Rm 3090 \\ Lawrence, KS 66045-7590}

Broadie, Alexander, ed. The Cambridge Companion to the Scottish Enlightenment. New York: Cambridge UP, 2003.

Brogan, Walter A. Heidegger and Aristotle: The Twofoldedness of Being. Albany, NY: SUNY Press, 2005.

Baumann, Peter and Betzler, Monika. Practical Conflicts: New Philosophical Essays. New York: Cambridge UP, 2004.

Craig, Edward, ed. The Shorter Routledge Encyclopedia of Philosophy. New York: Routledge, 2005.

Cutrofello, Andrew. Continental Philosophy: A Contemporary Introduction. New York: Routledge, 2005.

Di Giovanni, George. Freedom and Religion in Kant and His Immediate Successors: The Vocation of Human Kind, 17741800. New York: Cambridge UP, 2005.

Grenberg, Jeanine. Kant and the Ethics of Humility: A Story of Dependence, Corruption, and Virtue. New York: Cambridge UP, 2005.

Guignon, Charles and Hiley, David R eds. Richard Rorty. New York: Cambridge UP, 2003.

Henning, Brian G. The Ethics of Creativity: Beauty, Morality, and Nature in a Processive Cosmos. Pittsburgh, PA: University of Pittsburgh, 2005. 
Jacquette, Dale, ed. Cambridge Companion to Brentano. New York: Cambridge UP, 2004

Newton, Isaac. Philosophical Writings. ed. Andrew Janiak. New York: Cambridge UP, 2004.

Kant, Immanuel. The Cambridge Edition of the Works of Immanuel Kant: Notes and Fragments. Translated by Curtis Bowman, Paul Guyer, and Frederick Rauscher. New York: Cambridge UP, 2005.

Lear, Jonathan. Freud. New York: Routledge, 2005.

Longuenesse, Beatrice. Kant on the Human Standpoint. New York: Cambridge UP, 2005.

Ott, Walter. Locke's Philosophy of Language. New York: Cambridge UP, 2004.

Perkins, Franklin. Leibniz and China: A Commerce of Light. New York: Cambridge UP, 2004.

Stern, David G. and Szabados, Bela. Wittgenstein Reads Weininger. New York: Cambridge UP, 2004.

Strange, Stephen K. and Jack Zupko. Stoicism: Traditions and Transformations. New York: Cambridge UP, 2004.

Van der Eijk, Philip. Medicine and Philosophy in Classical Antiquity: Doctors and Philosophers on Nature, Soul, Health, and Disease. New York: Cambridge UP, 2005.

Vandevelde, Pol. The Task of the Interpreter: Text, Meaning, and Negotiation. Pittsburgh, PA: University of Pittsburgh Press, 2005.

Watkins, Eric. Kant and the Metaphysics of Causality. New York: Cambridge UP, 2005.

Westphal, Kenneth: Kant's Transcendental Proof of Realism. New York: Cambridge UP, 2004 